Asian J Agric \& Biol. 2022(1).

$\mathrm{AJAB}$

DOI: $10.35495 / a j a b .2020 .12 .575$

Original Article

\title{
Isolation and characterization of novel Rhodobacter spp. with the sodium removal ability from mangrove forest sediment in Southeast Vietnam
}

\begin{abstract}
Ngo Duc Duy1,2*, Duong Thi Hong Dao',2, Nguyen Hoang Dung1,2, Vu Thi Tuyet Nhung1, Pham Anh Vu1, Le
Quynh Loan', Huynh Thi Diep1, Pham Thanh Luu1,2, Hoang Quoc Khanh',2

${ }^{1}$ Institute of Tropical Biology, Vietnam Academy of Sciences and Technology, Ho Chi Minh city, Vietnam

${ }^{2}$ Graduate University of Sciences and Technology, Vietnam Academy of Sciences and Technology, Ho Chi Minh city, Vietnam

Received:

December 14, 2020

Accepted:

June 19, 2021

Online First:

November 03, 2021

Published:

January 09, 2022

Abstract

Salt contamination is one of the major problems of agricultural land. It is important to find new bacteria with sodium removal ability, which can be used to reduce salts from soils. This study aims to isolate and characterize the novel Rhodobacter spp. with the sodium removal ability from mangrove forest sediment in Southeast Vietnam. After screening of morphological characteristics of the cell size, shape, and presence of protrusions, seven strains were identified. The results also showed that these strains were able to reduce $\mathrm{NaCl}$ from Glutamate-malate medium (GM). The concentration of $\mathrm{NaCl}$ decreased from $28.57 \%$ to $36.42 \%$ for the treatment with 25 ppm $\mathrm{NaCl}$ after 14 days of incubation. However, in the $35 \mathrm{ppm} \mathrm{NaCl}$ concentration was absorb proficiency of decrease by approximately $5 \%$ compare with the $25 \mathrm{ppm}$ $\mathrm{NaCl}$ concentration. The gene sequences of the 16S rDNA and puMf gene regions of the isolated strains shared high similarities with genus Rhodobacter, which were identified as Rhodobacter sphaeroides and Rhodobacter johrii. Our results showed a high diversity in the isolated strains belonging to the Rhodobacter species with sodium absorption ability. This study suggests the possibility of using isolated Rhodobacter strains to remove salinity from soils.
\end{abstract}

Keywords: Collection, Mangrove forest, Salinity, Reduce, Rhodobacter spp.

\section{How to cite this:}

Duy ND, Dao DTH, Dung NH, Nhung VTT, Vu PA, Loan LQ, Diep HT, Luu PT and Khanh HQ, 2022. Isolation and characterization of novel Rhodobacter spp. with the sodium removal ability from mangrove forest sediment in Southeast Vietnam. Asian J. Agric. Biol. 2022(1): 202012575. DOI: https://doi.org/10.35495/ajab.2020.12.575 This is an Open Access article distributed under the terms of the Creative Commons Attribution 3.0 License.
(https://creativecommons.org/licenses/by/3.0), which permits unrestricted use, distribution, and reproduction in any medium, provided the original work is properly cited

\section{Introduction}

Purple phototrophic bacteria (PPB) are photosynthetic bacteria that are commonly employed in wastewater treatments due to their absorption capability of heavy metals (HMs), such as $\mathrm{Hg}$, As, $\mathrm{Cd}, \mathrm{Pb}, \mathrm{Cr}$ and $\mathrm{Cu}$ (Watanabe et al., 1998, 2003; Xu and Jia, 2011; Sasaki et al., 2012). PPB are also utilized to produce biofuel, secondary compounds and nutrients. The study in Thailand indicated that the two purple nonsulfur bacteria (PNSB) strains Rhodobium marinum NW16 and Rhodobacter sphaeroides KMS24 isolated from shrimp pond sediment have the ability to removal various HMs 
(maximum of 39\%) from contaminated shrimp pond water, and with removal ability of the NW16 strain was even higher in wastewater with the presence of $3 \% \mathrm{NaCl}$ (Panwichian et al., 2011). The Rhodobacter species was also reported with the removal capability of radionuclides such as $\mathrm{Co}, \mathrm{Sr}$ and $\mathrm{U}$ at a rate of $58 \%, 82 \%$ and $95 \%$, respectively (Sasaki et al., 2012; Sasaki and Takeno, 2014).

In addition, the photosynthetic bacteria were reported with the ability of denitrification of aging biogas slurry from livestock farm and chemical oxygen demand (COD) from municipal wastewater (Anpi et al., 2017; Stefania et al., 2017). The reported that the Rhodopseudomonas species was a promising candidate for denitrification of aging biogas slurry and swine sewage wastewater (Anpi et al., 2017; Hongyi et al., 2016) and that the highest removal efficiency of $\mathrm{NH}_{3}-\mathrm{N}$ reached $99.75 \%$ in aging biogas slurry. In municipal wastewater, the removal efficiency of $\mathrm{NH}_{3}-\mathrm{N}$, that of $\mathrm{NH}_{4}$ and COD reached $95 \%, 70 \%$ and $69 \%$, respectively (Anpi et al., 2017; Stefania et al., 2017). Other strains of photosynthetic bacteria were reported with a lower removal capability of NH3 and NH4 (Ahmadldi et al., 2015). In another study, PPB was able to simultaneously remove $88 \%$ of phosphorous from primary settled domestic wastewater (Tim et al., 2014, 2016). Photosynthetic bacteria were combined with vegetables to remove total phosphorous, total nitrogen, COD, ammonia, nitrate, and nitrite from shrimp wastewater (Luo et al., 2012).

Another function of photosynthetic bacteria is removal of dyes. Some strains were utilized in the treatment of color contaminants in textile industries. The removal of color is attributed to the azoreductase enzyme, in photosynthetic bacteria species, such as Rhodopseudomonas palustris (AS1.2352), $R$. blasticus, $R$. adriaticus, $R$. capsulatus and Rhodovulum strictrum. These species contain the azoreductase compound which has ability of decolorization of color or photosynthetic bacterial biofilms (Elizabeth et al., 2003). The Rhodobacter capsulatus and $R$. sphaeroides species have been widely investigated as model organisms for anoxygenic photosynthesis, nitrogen and carbon fixation and chemotaxis (Lang et al., 2012). $R$. capsulatus strain is a model organism of the photosynthetic bacteria group, which is representative for the study of a gene transfer $(\mathrm{Wu}$ and Bauer, 2008; Masepohl and Hallenbeck, 2010). Recently, the microbial desalination cell (MDC) has been applied as a new method to reduce the salinity in water and soils (Xiaoxin et al., 2009; Luo et al., 2011; Ahmed et al., 2014). This method is promising because water desalination can be accomplished without electrical energy input or high water pressure by using a source of organic matter as the fuel to desalinate water (Xiaoxin et al., 2009). The used a microbial desalination cell as a reverse osmosis pre-treatment method to remove salinity from water. For a $30-35 \mathrm{~g} \mathrm{NaCl} / \mathrm{L}$ treatment, their results demonstrated substantial approximately 43$67 \%$ desalination, a sodium removal efficiency $>90 \%$ and an increase in desalination a sodium concentration of 98 - 99\% (Maha et al., 2010; Ahmed et al., 2014; Younggy and Logan, 2011; Kim and Logan, 2011; Luo et al., 2011). The performance of the microbial desalination cell can be improved by using an electrodialysis stack and concentrating cells.

However, the information and database on microbial desalination remain limited. Only a limited number of species for biodesalination have been reported, such as two bacterial, R.sphaeroides SSI and Rhodovulum sp. and two cyanobacteria Synechocystis sp. PCC 6803 and Synechococcus sp. PCC 7002 (Kei et al., 2017; Jaime et al., 2014). Thus screening, selecting and collecting microbial communities for research and application of salinity reduction is a very urgent request for agriculture. This study, which focused on finding photosynthetic bacteria, has the potential to remove sodium from mangrove forests. The results of this study are promising for the application of microbial desalination in agriculture by seawater intrusion, which is causing rising seawater levels, due to global climate change.

\section{Material and Methods}

\section{Isolation of photosynthetic bacteria}

Sediment and water samples were collected from the mangrove forest in the $\mathrm{Ca}$ Mau Biosphere Reserve of the United Nations Educational, Scientific and Cultural Organization (UNESCO), Vietnam. Photosynthetic bacteria were isolated by transferring a $1 \mathrm{ml}$ or $1 \mathrm{~g}$ sample into a $5 \mathrm{ml}$ tube containing the GM medium or modified GM medium (added sodium at a concentration of $35 \mathrm{ppm}$ ) (Kei et al., 2017). All samples were grown under light ( $c a .3000$ lux) for approximately 7 days. After incubation, we chose the samples with a red, red-brown or dark red collor and then performed the streaked method onto 
GM agar, selected a single colony. The morphological characteristics reveal Gram-negative bacteria with varied shapes, such as spherical, rod, arc and spiral shapes. The diameters of the cells range from approximately $0.3-1.5 \mu \mathrm{m}$ (Imhoff, 1992).

\section{Screening of Rhodobacter spp. with sodium removal ability}

The count method was employed to measure the biomasses of the bacterial cells in the culture process by absorption spectrometry nephelometry at $\mathrm{OD}_{660 \mathrm{~nm}}$. The cells were washed 3 times in the $60 \%$ sucrose solution and were taken as the control group to calculate the absorption spectra (Feng, 2016). The culture was incubated in a screw cap test tube containing $18 \mathrm{ml}$ of GM broth in a $15 \times 150 \mathrm{~mm}$ tube with the addition of $10 \%(\mathrm{v} / \mathrm{v})$ of stock bacteria solution. The samples were incubated in room temperature with a light intensity of 3,000 lux for 2 days and with $\mathrm{NaCl}$ concentration of $35 \mathrm{ppm}$ in the medium. The growth rate of photosynthetic bacteria was observed at $\mathrm{OD}_{660 \mathrm{~nm}}$. The sodium concentration was measured with a spectrophotometer and ATAGO equipment. The strains selected for the screening had growth rates exceeding 0.5. Bacteria strains with a resistant ability at $35 \mathrm{ppm} \mathrm{NaCl}$ in broth $\mathrm{GM}$ were collected. The culture broth was centrifuged at $10,000 \times \mathrm{g}$ for $20 \mathrm{~min}$ in $4^{\circ} \mathrm{C}$ to isolate the supernatant, and then the sodium concentration was measured.

\section{Identify Rhodobacter spp.}

Bacterial cells were grown under anaerobic conditions at a light intensity (ca. 3000 lux) in broth $\mathrm{GM}$ at room temperature. The cells were collected by centrifuge in the growth phase after 4 days and then extracted using isolated genomics DNA with QIAGEN kit. Amplification and analysis of $16 \mathrm{~S}$ rDNA sequences was carried out with eubacterial universal primer $27 \mathrm{~F}$ and $1492 \mathrm{R}$ and special primer pufM 557F and 750R of the photosynthetic bacteria group (Lane, 1991; Laurie et al., 2001). All of the polymerase chain reaction (PCR) products were purified by using a QIAGEN kit before sequencing.

Primers and PCR amplification.

To identify the photosynthesis bacteria, the $16 \mathrm{~S}$ rDNA gene and specific pufM gene were amplified by using the $27 \mathrm{~F}$ forward primer (5'AGAGTTTGATCMTGGCTCAG-3') and 1492R reverse primer (5'-GGTTACCTTGCTATGACTT- $3^{\prime}$ ), and the specific pufM primer $557 \mathrm{~F}$ (5'CGCACCTGGACTGGAC-3') and 750R (5'CCCATGGTCCAGCCAGAA-3'), respectively (Laurie et al., 2001). The PCR amplification was prepared in a volume of $25 \mu \mathrm{L}$ containing $1 \mu \mathrm{l}$ of DNA, $9.5 \mu \mathrm{l}$ of Master mix 1X (Bioline), $1 \mu \mathrm{l}$ of per primer, $1 \mu \mathrm{l}$ of DNA template (ca. $100 \mathrm{ng}$ ) and nuclease-free water. For the amplification of the 27F and $1492 \mathrm{R}$ primers, the conditions were in the cycled first step at $94^{\circ} \mathrm{C}$ for $4 \mathrm{~min}$; repeated in the second step with 30 cycles at $94^{\circ} \mathrm{C}$ for 20 seconds, $54^{\circ} \mathrm{C}$ for 15 seconds and $72^{\circ} \mathrm{C}$ for 45 seconds; a continuous extension step was performed at $72^{\circ} \mathrm{C}$ for $10 \mathrm{~min}$ and a final step at $4^{\circ} \mathrm{C}$. For the pufM 557F and 750R primers, the amplification was cycled at $94^{\circ} \mathrm{C}$ for 3 min, followed by 30 cycles at $94^{\circ} \mathrm{C}$ for $1 \mathrm{~min}, 55^{\circ} \mathrm{C}$ for $1 \mathrm{~min}$ and $72^{\circ} \mathrm{C}$ for $1 \mathrm{~min}$. An extension step was performed at $72^{\circ} \mathrm{C}$ for $10 \mathrm{~min}$, and a final step at $4^{\circ} \mathrm{C}$. Sequences and phylogenetic analysis.

The sequences of the $16 \mathrm{~S}$ rDNA region and pufM gene have been popular for gene identification of bacteria taxonomy. In addition, the pufM gene is specific to identify the photosynthetic bacteria. They were compared with reference sequences downloaded from the National Center for Biotechnology Information (NCBI) database and aligned by using Clustal X (Thompson et al., 1997). The phylogenetic tree was constructed from the evolutionary distance data (Kimura, 1980) using the neighbor-joining method (Saitou and Nei, 1987). The bootstrap method based on 1,000 random repeated was employed for the sequence analysis (Felsenstein, 1985). Furthermore, in the phylogenic trees were determined by contributions from group members of the genus Rhodobacter spp. with separation of other Bacillus genera.

\section{Results and Discussion}

\section{Isolation of Rhodobacter spp.}

Rhodobacter were isolated from 78 sediment and water samples collected from mangrove forests in the Ca Mau biosphere reserve of UNESCO, Vietnam. In total, 48 strains were isolated and selected from GM agar medium after purification by restreaking on the plate. All strains were identified as Gram-negative, oval or rod - shaped cell under a microscope and the seven strains with the highest sodium removal ability were selected (Table 1). Our results showed that isolated the strains had the same morphological 
characteristics as the Rhodobacter species (Imhoff et al., 1984).

Table-1: Morphology cell and Gram of isolated bacteria

\begin{tabular}{|c|c|c|}
\hline The strains & Morphology cell & Gram \\
\hline CM4.2 & rods shaped & Negative \\
\hline CM8 & rods shaped & Negative \\
\hline CM15 & rods shaped & Negative \\
\hline CM37 & rods shaped & Negative \\
\hline CM53.2 & rods shaped & Negative \\
\hline CM58.1 & rods shaped & Negative \\
\hline CM63.3 & Ovals/rods shaped & Negative \\
\hline
\end{tabular}

\section{Screening of Rhodobacter spp. with sodium removal ability}

The 48 strains were able to grow in GM broth for 14 days; all strains had been grown well. In GM with 25 ppm NaCl, only 7 strains (CM53.2, CM58.1, CM8, CM37, CM4.2, CM63.3 and CM15) survived and grew (Fig. 1a) after incubation. They were selected as strains with sodium removal ability in this study.

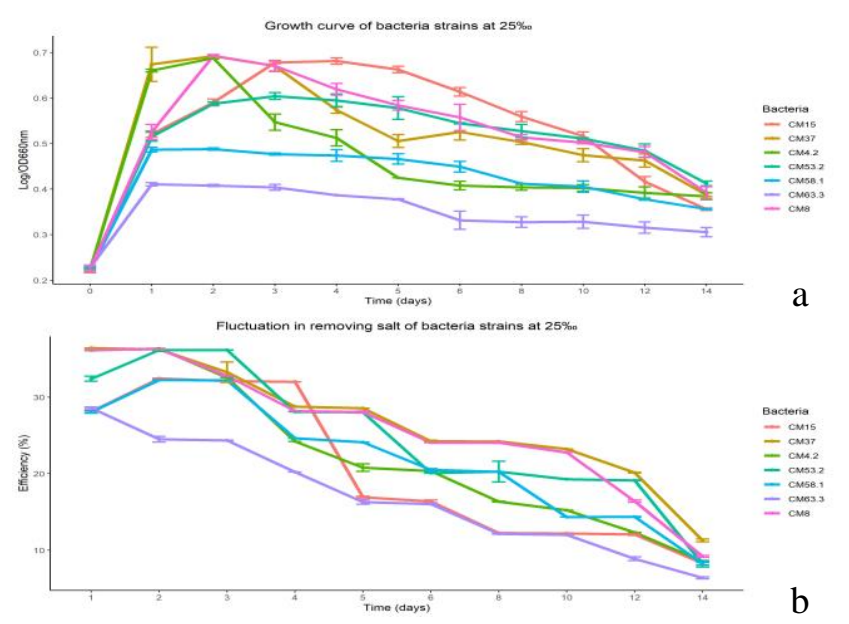

Figure-1: Growth and sodium removal by seven strains (CM53.2, CM58.1, CM8, CM37, CM4.2, CM63.3 and CM15) at 25 ppm NaCl treatment.

The removal rate showed significant differences between the $25 \mathrm{ppm}$ and $35 \mathrm{ppm} \mathrm{NaCl}$ treatments. In most strains, the removal efficiencies for the $35 \mathrm{ppm}$ $\mathrm{NaCl}$ treatment were lower than the removal efficiency in the $25 \mathrm{ppm}$ treatment with a decrease from $1 \%$ to $5 \%$, depending on the growth of the strains (Fig. 1b, Fig. 2a,b). Our results indicated that sodium concentration affected the salinity removal capability during the first few days. The results of this study show agreement with the report indicated that Rhodobacter was able to remove sodium with a removal efficiency of $39.3 \%$ in a $3 \% \mathrm{NaCl}$ treatment (Kei et al., 2017). In another report, they found that both Rhodobacter strains (NW16 and KSM24 strains) can remove a maximum of $31 \%$ of $\mathrm{Na}$ from water that contained 3\% $\mathrm{NaCl}$ (Panwichian et al., 2011; Saijai et al., 2010). Our study confirmed the promising sodium removal ability of some Rhodobacter species in desalination from Vietnam.

The sodium removal was dependent on the pathway of photosynthetic metabolism and respiration through the chloride and sodium pump. The light energy directs is affects the halorhodopsin protein of the chloride pump onto the membrane cell in a study of Halobacterium halobium strain (Dohrmann and Müller, 1999). In the desalination phase, the light will makes chloride pump of opening and $\mathrm{Cl}^{-}$import into the cell, which will then change the membrane potential $(\mathrm{Vm})$ inside and outside the cell. The sodium pump will open and draw $\mathrm{Na}^{+}$into the cell by Cyanobacteria species, which means that sodium as removed from the environment (Dimroth, 1990; Jaime et al., 2014; Minas et al., 2015).

The pathways of the metabolic bacteria are based on their life cycle. Thus, the salinization processing also depends on the growth phase and nutrients in the experiments. Sodium ion is necessary for metabolism bacteria pathways, such as nutrient uptake (e.g., $\mathrm{Na}^{+}$/ $\mathrm{HCO}^{2}$ transport), cell division (e.g., in heterotrophic cyanobacteria), nitrate assimilation, nitrogen fixation and photosynthesis (Apte and Thomas, 1983; Maeso et al., 1987; Espie et al., 1988). With the species R.sphaeroides SSI, the rate is higher with Na removal after 2 days of cultivation under static light conditions. In another case, the Na concentration was reduced after cultivation for 8 days under aerobic dark conditions with Rhodovulum sp. (Kei et al., 2017). The cell growth characteristics of $R$. sphaeroides O.U.001 showed the start of exponential growth phases in $24 \mathrm{~h}$ and the stationary phase in 80 $h$ (Nitai and Debabrata, 2009).

From the $1^{\text {st }}$ day to the $4^{\text {th }}$ day, the strains depended on the lag phase, log phase and stationary phase. They had an exponential increase in the number of living bacterial cells and cell division. Therefore, sodium ion has increased the absorption of sodium into the cells. Especially, the receptive capacities of the cell of each strain is completely different and limited. In our experiments, the results show that the salt removal potential decreases with the passage of time, 
which was suitable in the growth phase of the Rhodobacter species in sodium concentration medium (Fig. 1b and Fig. 2b).

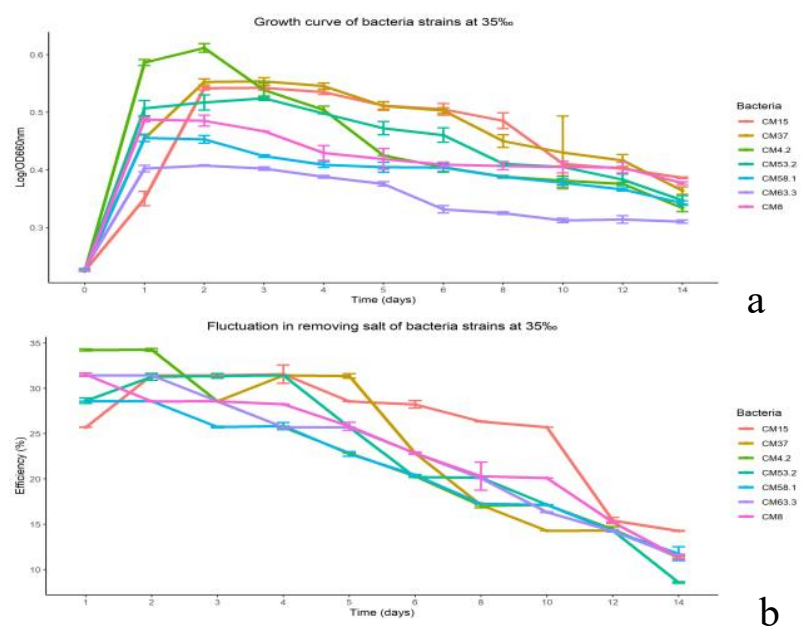

Figure-2: Growth and sodium removal by seven strains (CM53.2, CM58.1, CM8, CM37, CM4.2, CM63.3 and CM15) at 35 ppm NaCl treatment.

Identify Rhodobacter spp. belongs to the $16 \mathrm{~S}$ rDNA and puMf sequences gene

The phylogenetic tree of $16 \mathrm{~S}$ rDNA gene sequences showed that the seven isolated strains from this study located in clusters within the genus of Rhodobacter (Fig. 3). Our sequences were aligned with the gene database of known bacteria using the BLAST tool. They are similar and are considered to represent a single species. In this case, these strains CM37, CM63.3 and CM4.2 were closely related to Rhodobacter johrii, and four strains belong to $R$. sphaeroides (Fig. 3).

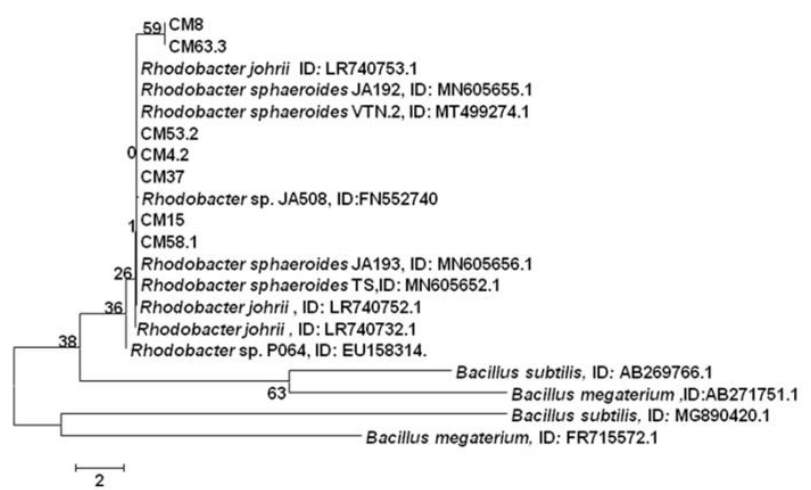

Figure-3: Phylogenetic tree for seven strains of Vietnam constructed by the neighbor-joining method based on $27 \mathrm{~F}$ and $1492 \mathrm{R}$ primers.
However, the phylogenetic tree of the pufM gene sequences showed that three of seven strains (CM58.1, CM37 and CM15) were closely related to Rhodobacter johrii and four other strains have high similarity with $R$. sphaeroides (Fig. 4). Our results suggested that seven of our strains belong to Rhodobacter genus and are closely related $R$. johrii and $R$. sphaeroides.

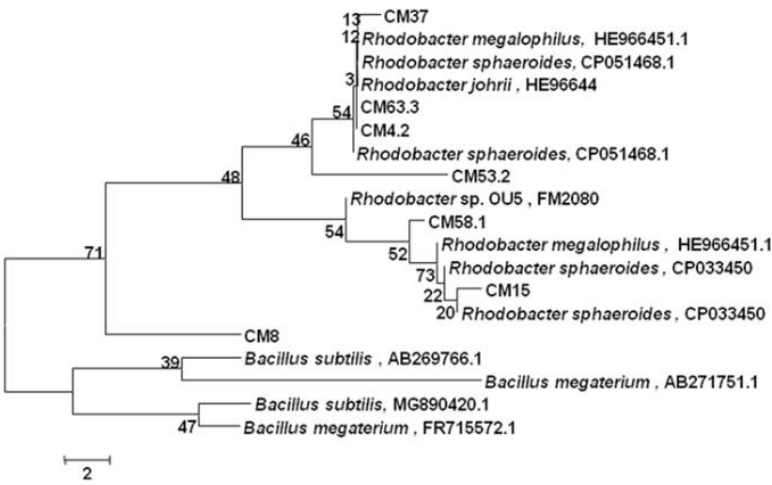

Figuge-4: Phylogenetic tree for seven strains of Vietnam constructed by the neighbor-joining method based on puMf 557F and puMf 570R primers.

Our strains, namely, CM37, CM8.1 and CM15, shared $98.28 \%$ similarity to $R$. johrii (Girija et al., 2009). The puMf sequences gene of these three trains were submitted to the GenBank database with accession numbers MT645162, MT645163 and MT645164. On the other hand, the 16S rRNA gene was accepted as a new species with a similarity of 97\% (Stackebrandt and Goebel, 1994). In yeast species, when nucleotide shown a difference of $1 \%$ or more in the D1/D2 domain, it indicates a difference in species (Kurtzman and Robnett, 1998). The puMf gene of the $R$. johrii strain in the database description was verified (Girija et al., 2009).

\section{Conclusion}

In this study, seven strains of photosynthesis bacteria belonging to Rhodobacter genus were isolated from the mangrove forests in the $\mathrm{Ca}$ Mau Biosphere Reserve in Southeast Vietnam. The bacteria are Gram-negative with oval- or rod-shape cells and were morphologically identified as Rhodobacter spp. The results of $16 \mathrm{~S}$ rDNA and puMf gene sequences indicated that they were closely related to $R$. sphaeroides and $R$. johrii. The results also confirmed that all seven strains have ability to remove sodium 
from GM medium with removal efficiency from $28.57 \%$ to $36.42 \%$ in the $25 \mathrm{ppm} \mathrm{NaCl}$ treatment. The removal efficiency decreased in the higher $\mathrm{NaCl}$ treatment at $35 \mathrm{ppm}$. Our results suggested that all strains have the potential for desalination and could be utilized for biodesalination in agricultural environments.

\section{Acknowledgment}

The author would like to thank the Department of Science and Technology Ho Chi Minh city for providing financial support for this study, and the Science Council.

Disclaimer: None.

Conflict of Interest: None.

Source of Funding: This research was funded by The Department of Science and Technology Ho Chi Minh city, Vietnam under grant No. 48/2019/HĐQPTKHCN.

\section{References}

Ahmadldi I, Zaharah I, Shara EM and Zaiton AM, 2015. Biokinetics of nitrogen removal at high concentrations by Rhodobacter sphaeroides ADZ101. Int. Biodeterior. Biodegrad. 105: 245251.

Ahmed E, Hegab HM and Pant D, 2014. The nearfuture integration of microbial desalination cells with reverse osmosis technology. Energy Environ. Sci. 7: 3921-3933.

Anpi Y, Guangming Z, GuangY, Hangyao W, Fan M, Hong CW and Meng P, 2017. Denitrification of aging biogas slurry from livestock farm by photosynthetic bacteria. Bioresourc. Technol. 232: 408-411.

Apte SK and Thomas J, 1983. Sodium transport in filamentous nitrogen fixing cyanobacteria. J Biosci. 5: 225-233.

Bruno H, Luciana SR, Cláudia BL, Paula F, Rui JRM, Duart AC, Parpal MA and Pereira E, 2015. Study on bioaccumulation and biosorption of mercury by living marine macroalgae: Prospecting for a new remediation biotechnology applied

saline waters. Chem. Eng. J. 281: 759-770.

Dimroth P, 1990. Mechanisms of sodium transport in bacteria. Philos. Trans. Royal Soc. Lond. B Biol. Sci. 326(1236): 465-77.
Dohrmann AB and Müller V, 1999. Chloride dependence of endospore germination in Halobacillus halophilus. Arch Microbiol. 172: 264-267.

Elizabeth KW, Carolina P, Walter M and Ann CW, 2003. Production and nutrient removal by periphyton grown under different loading rates of anaerobically digested flushed dairy manure. J. Phycol. 39(6):1275-1282.

Espie GS, Miller AG and Canvin DT, 1988. Characterization of the $\mathrm{Na}$ requirement in cyanobacterial photosynthesis. Plant Physiol. 88: 757-763.

Felsenstein J, 1985. Confidence limits on phylogenies: An approach using the bootstrap. Evol. 39: 783-791.

Feng XF, 2016. Applied research of microbial degradation of high-concentration organic wastewater. Chem. Eng. Transact. 55: 133-138.

Girija KP, Sasikala C, Ramana C, Sproer V, Takaichi C, Thiel V and Imhoff JF, 2009. Rhodobacter johrii sp. nov., an endospore-producing cryptic species isolated from semiarid tropical soils. Int. J. Syst. Evol. Microbiol. DOI: 10.1099/ijs.0.011718-0.

Hongyi W, Suguru O, Takeshi Y, Yuto K and Hiroto $\mathrm{M}, 2016$. Isolation and characterization of a purple nonsulfur photosynthetic bacterium Rhodopseudomonas faecalis strain a from swine sewage wastewater. Biocontrol Sci. 21 (1); 2936.

Imhoff JF, 1992. Taxanomy, phylogeny and general ecology of anoxygenic phototrophic bacteria. Mann. N. H.; Carr, N. G., (Eds.). Bergey's manual of determinative bacteriology. Plenum press, New York, USA.

Imhoff JF, Truper HG and Pfenning, 1984. Rearrangement of the spercies and genera of the phototrophic "Purple nonsulfur bacteria". JISB. 34: 340-343.

Jaime MA, Anna A, Catherine AB, Tom B, Catherine JG, Annegret H, Esther K, Linda L, Mary AM, Konstantinos M and Michael R, 2014. Biodesalination: A Case Study for Applications of Photosynthetic Bacteria in Water Treatment. Plant Physiol. 164: 1661-1676.

Kei S, Yuichiro H, Kenji T and Ken S, 2017. Removal of sodium from seawater medium using photosynthetic bacteria. J. Agric. Chem. Environ. 6: 133-143.

Kim Y and Logan B, 2011. Series assembly of 
microbial desalination cells containing stacked electrodialysis cells for partial or complete seawater desalination. Environ. Sci. Technol. 45: 5840-5845.

Kimura M, 1980. A simple method for estimating evolutionary rate of base substitutions through comparative studies of nucleotide sequences. J. Mol. Evol. 16: 111-120.

Kurtzman CP and Robnett CJ, 1998. Identification and phylogeny of ascomycetous yeasts from analysis of nuclear large subunit (26S) ribosomal DNA partial sequences. Antonie van Leeuwenhoek. 73: 331-371.

Lane DJ, 1991. 16S/23SrRNA sequencing. Stukebrandet, E.; Goodfellow, M., (Eds.), Nucleic acid techniques in bacterial systematic. John Wiley and Sons, New York, USA.

Lang AS, Zhaxybayeva O and Beatty JT, 2012. Gene transfer agents: phage-like elements of genetic exchange. Nat. Rev. Microbiol. 10(7): 472-482.

Laurie AA, Jennifer C and Michael TM, 2001. Photosynthetic and Phylogenetic Primers for Detection of Anoxygenic Phototrophs in Natural Environments. Appl. Environ. Microbiol. 67(7): 2922-2926.

Luo H, Jenkins PE and Ren Z, 2011. Concurrent desalination and hydrogen generation using microbial electrolysis and desalination cells. Environ. Sci. Technol. 45: 340-344.

Luo W, Deng X, Zeng W and Zheng D, 2012. Treatment of wastewater from shrimp farms using a combination of fish photosynthetic bacteria, and vegetation, Desalin. Water Treat. 47 (1-3): 221-227.

Maeso ES, Piñas FF, Gonzalez MG and Valiente EF, 1987. Sodium requirement for photosynthesis and its relationship with dinitrogen fixation and the external $\mathrm{CO}_{2}$ concentration in cyanobacteria. Plant Physiol. 85: 585-587.

Maha M, Tomonori S, Jingling Y, Michael $\mathrm{H}$, Xiaoxin $\mathrm{C}$, Xia $\mathrm{H}$ and Bruce EL, 2010. Using microbial desalination cells to reduce water salinity prior to reverse osmosis. Energy Environ. Sci. 3: 1114-1120.

Masepohl B and Hallenbeck PC, 2010. Nitrogen and molybdenum control of nitrogen fixation in the phototrophic bacterium Rhodobacter capsulatus. Adv. Exp. Med. Biol. 675: 49-70.

Minas K, Karunakaran E, Bond T, Gandy C, Honsbein C, Madsen M, Amezaga J, Amtmann
A, Templeton $\mathrm{M}$ and Biggs C, 2015. Biodesalination: an emerging technology for targeted removal of $\mathrm{Na}+$ and $\mathrm{Cl}-$ from seawater by cyanobacteria. Desalinat. Water Treat. 55(10): 2647-2668.

Nitai B and Debabrata D, 2009. Photofermentative hydrogen production using purple non-sulfur bacteria Rhodobacter sphaeroides O.U.001 in an annular photobioreactor: A case study. Biomass and Bioenergy. 33: 911-919.

Panwichian S, Kantachote D, Wittayaweerasak B and Mallavarapu M, 2011. Removal of heavy metals by exopolymeric substances produced by resistant purple nonsulfur bacteria isolated from contaminated shrimp ponds. Electron. J. Biotechnol. 14 (4): http://dx.doi.org/10.2225/.

Saijai P, Duangporn K, Banjon W and Megharaj M, 2010. Isolation of purple nonsulfur bacteria for the removal of heavy metals and sodium from contaminated shrimp ponds. Elect. J. Biotechnol. 13(4). DOI: 10.2225/vol13-issue4-fulltext-8.

Saijai P, Duangporn K, Banjong W and Megharaj M, 2011. Removal of heavy metals by exopolymeric substances produced by resistant purple nonsulfur bacteria isolated from contaminated shrimp ponds. Elect. J. Biotechnol. 14(4): DOI: 10.2225/vol14-issue4-fulltext-2.

Saitou N and Nei M, 1987. The neighbor-joining method: A new method for reconstructing phylogenetic trees. Mol. Biol. Evol. 4: 406-425.

Sasaki K, Hara C, Takeno T, Okuhata H and Miyasaka H, 2012. Metals related to radionuclides and heavy metals removal using photosynthetic bacteria immobilized recovery type porous ceramic. Japan. J. Water Treat. Biol. 46: 119-127.

Sasaki K, Morikawa H, Kishibe T, Takeno K, Mikami A, Harada T and Ohta M, 2012. Simultaneous removal of cesium and strontium using a photosynthetic bacterium, Rhodobacter sphaeroides SSI immobilized on porous ceramic made from waste glass. Adv. Biosci. Biotechnol. 4: 6-13.

Sasaki K and Takeno K, 2014. Practical Decontamination of Radioactive Polluted Soil by Photosynthetic Bacteria and Recycle Use for Agriculture. Seibutu-Kougaku Kaishi. 92: 146156.

Stackebrandt E and Goebel B, 1994. Taxonomic Note: A Place for DNA-DNA Reassociation and 16S rRNA Sequence Analysis in the Present 
Species Definition in Bacteriology. Int. J. Syst. Bacteriol. 44: 846-849.

Stefania C, Saverio G, Irene R, Simone P, Paolo P and Elena T, 2017. Potential of rhodobacter capsulatus grown in anaerobic-light or aerobicdark conditions as bioremediation agent for biological wastewater treatments. Water. 9(2): 108.

Thompson JD, Gibson TJ, Plewniak F, Jeanmougin F and Higgins JD, 1997. The Clustal X windows interface: Flexible strategies for multiple sequence alignment aided by quality analysis tools. Nucleic Acids Res. 24: 4876-4882.

Tim H, Barry EM, Lu Y, Puyol D, Keller J and Batstone DJ, 2016. Domestic wastewater treatment with purple phototrophic bacteria using a novel continuous photo anaerobic membrane bioreactor. Water Res. 100:486-495.

Tim H, Damien JB and Jürg K, 2014. Phototrophic bacteria for nutrient recovery from domestic wastewater. Water Res. 50: 18-26.

Watanabe M, Kawahara K, Sasaki K and Noparatnaraporn N, 2003. Biosorption of cadmium ions using photosynthetic bacterium, Rhodobactersphaeroides $\mathrm{S}$ and a marine photosynthetic bacterium, Rhodovulum sp. and their biosorption kinetics. J. Biosci. Bioeng. 95: 374-378.

Watanabe M, Sasaki K, Nakashimada T, Noparatnaraporn N and Nishio N, 1998. Growth and flocculation of a marine photosynthetic bacterium Rhodovulum sp. Appl. Microbiol. Biotechnol. 50: 682-691.

Wu J and Bauer CE, 2008. RegB/RegA, a global redox-responding two component system. Adv. Exp. Med. Biol. 631: 131-148.

Xiaoxin C, Huang X, Liang P, Xiao P, Zhou Y, Zhang $X$ and Logan BE, 2009. A new method for water desalination using microbial desalination cells. Environ. Sci. Technol. 43: 7148-7152.

$\mathrm{Xu} \mathrm{D}$ and Jia P, 2011. Construction and characterization of a photosynthetic bacterium genetically engineered for $\mathrm{Hg}{ }^{2+}$ uptake. Bioresour. Technol. 102 (3): 3083-3088.

Younggy K and Logan B, 2011. Series assembly of microbial desalination cells containing stacked electrodialysis cells for partial or complete seawater desalination. Environ. Sci. Technol. 45: 5840-5845.

\section{Contribution of Authors}

Duy ND: Conceived the idea, designed research methodology, literature review, data analysis and interpretation, manuscript final writing and reading

Dao DTH: Designed research methodology, sampling and data collection

Dung NH: Designed research methodology, literature review, and interpretation, manuscript writing

Nhung VTT, Vu PA, Loan LQ \& Diep HT:

Sampling and data collection

Luu PT: Literature review, data analysis and manuscript writing

Khanh HQ: Literature review and interpretation, manuscript final reading 